\title{
PUSHKIN'S TATIANA
}

This essay first appeared in an anthology edited by Sona Stephan Hoisington, A Plot of Her Own. The Female Protagonist in Russian Literature (Evanston: Northwestern University Press, 1995): 6-20. Delivered in a compressed Russian version in 1995 at a conference at Moscow State University honoring the Centenary of V. V. Vinogradov and published in its Proceedings (Vestnik Moskovskogo universiteta, seriia 9, Filologiia [no. 6, 1995]: 3147), it caused a minor fracas. Its reprinting in the Bulletin of Tambov University (Vestnik Tambovskogo universiteta, vol. 3-4, 1996: 36-46) added still more fuel to that fracas. The Tambov "Tatiana" stimulated such negative commentary from the pen of one local professor, who so completely failed to grasp my praise of Pushkin's heroine and fixated with such baffling earnestness on the essay's trivial remarks on sexual subtexts, that I ventured to submit a lengthy and unnecessarily confrontational "open letter" in defense of the piece. The editors graciously agreed to print it a year later, together with a final riposte from the offended professor (Vestnik Tambovskogo universiteta, vol. 4, 1997: 69-77).

Late in 1996 the essay received a probing, more open-minded review, delivered at a Pushkin conference in Pskov by a scholar from Novosibirsk State Pedagogical Institute. He suggested a "Nabokovian" source for my hypothesis, which interested me greatly, and also assigned pride of place for revisionist interpretations of the Russian classics not to a decadent, triumphant West eager to pervert Russia's sacred values, as had the Tambov professor, but to Russia's own critical tradition, especially Tynianov and the Formalists.

The negative Russian reaction to this essay was only partially due to the protective reflexes of the Tatiana cult. The piece could easily be read as enhancing that myth, not as debunking it. Nor can we wholly blame the raw post-communist 1990s - when, as censorship dissolved, Russian academics witnessed their Russian classics being subjected to all manner of slick, cavalier exploitation by Western critical theorists and irreverent outsiders (although that too played a role). The lesson to be learned from the acrimonious fallout of "Tatiana," I believe, was my inattentiveness to the grating, flippant sound of my hypothesis against the traditions of Russian philological scholarship. In the English original, my scenario for Chapter Eight of Eugene Onegin is cast as a "musing" conversation of the critic with herself; a speculation, a parallel world and simultaneously a shadow-reality mirroring the creative process. It does not exclude or discredit other readings. In the Russian version, this tentative intonation was greatly weakened; the essay (I realized too late) sounded preachy and polemical. Some Russian academic circles, tolerating playfulness from artists like Nabokov or Sinyavsky, found whimsical relations toward beloved subject matter disrespectful from a "foreign scholar." The fracas amounted to little in the end. But it was indicative of the clash between our two "Pushkin industries" 
(old versus new, hagiographic versus irreverent) after the Wall came down. Excerpts of this Tatiana aftermath are translated here as a postscript to the essay.

It could also be that my argument is simply wrong. Re-reading the essay now after fifteen years, it strikes me as naïve in its treatment of Romantic convention. But that Tatiana is the miracle of poetic tension and that Pushkin meant this as moral reality: that idea I stand behind. In retrospect, the comedy with Tambov illustrates avant la lettre Mikhail Gasparov's case against Bakhtinian readings, in which everyone (author, hero, reader, critic) is equally alive, eager to talk, and trustworthy. Such a literary thought experiment, Gasparov believed, was sooner bad philosophy than useful philology.

\section{TATIANA} (1995)

“[Tatiana], as is well known, besides being Onegin's ill-starred partner and the cold-blooded wife of the general, was Pushkin's personal Muse.... I even think that's the reason she didn't start anything up with Onegin and remained true to her unloved husband, so she'd have more free time to read and reread Pushkin and to languish over him."

- Abram Tertz [Andrei Sinyavsky], Strolls with Pushkin

“Простите мне, я так люблю / Татьяну милую мою.” [Forgive me: I so love my precious Tatiana.]

- The narrator, Eugene Onegin, chap. 4, xxiv

The heroine of Pushkin's Evgenii Onegin carries the most famous, deceptively complex female name in all of Russian literature. Paradoxes abound in her image, which is to varying degrees derivative, impulsive, naïve, renunciatory, passive, majestically disciplined and inexplicably faithful. Starting with the narrator who tells her story and ending with many successive generations of critics, almost everyone who touches this image falls in love with it - or with its unrealized potential. It could be argued that Tatiana and her exquisitely "withheld" personal fate functioned as the single, most richly inspirational source for Russian literary heroines well into the present century.

This essay grew out of my bewilderment over the Tatiana cult. What has made this collage of female attributes - sentimental, vulnerable, stubborn, 
largely silent - so resilient and irresistible? Tatiana's energies and virtues have been enormously inflated, by detractors as well as devotees. In one of the earliest portraits, Vissarion Belinsky, smitten by Tatiana but resisting the fate that Pushkin provides for her, lamented that she could not break free into her own autonomous life. ${ }^{1}$ Dostoevsky, pursuing the other extreme in his Pushkin Speech of 1880, elevated that fate to the level of hagiography by crediting Tatiana with every possible civic and metaphysical virtue, eventually investing her marital fidelity with the cosmic dimensions of Ivan Karamazov's challenge to an unjust universe. ${ }^{2}$ And then there is the troublesome denigration of Evgeny that usually attends the exaltation of Tatiana. He is made "superfluous" not only to his own life and times but also to the novel that bears his name; his honest and honorable actions vis-à-vis the rural maiden who thrust herself inopportunely upon him are read as mental cruelty, frivolity, even depravity. ${ }^{3}$ (Here, Tchaikovsky's wonderfully nuanced 1879 reworking of the novel into opera-"lyrical scenes" that probably should have been titled Tatiana - must figure as a crucial phase in the maturation of the cult.) To be sure, some eminent Pushkin scholars (Gukovsky, Bondi, Slonimsky, and Makogonenko in the Soviet period) have attempted a rehabilitation of Evgeny. This move is often linked, however, with an extra-textual and politically motivated hypothesis cobbled together from hints in the fragmentary chapter 10: since Evgeny was "becoming a Decembrist," he deserved Tatiana's support and the reader's sympathy. ${ }^{4}$ Perhaps more serious than these facts of reception or transposition is the disjointed image of Tatiana within the text itself. There are some

1 For Belinsky on Tatiana, see V. G. Belinskii, "Evgenii Onegin" A. S. Pushkina (Moscow: GosIzdKhudLit, 1957), esp. 59-84 (Stat'ia 9-ia).

2 Dostoevsky proclaimed in his Pushkin Speech (1880): "Perhaps Pushkin would have done better had he called his poem by Tatiana's name and not by Onegin's. She utters the truth of the poem." Fyodor Dostoevsky, "Pushkin," in Russian Views of Pushkin's "Eugene Onegin," ed. and trans. Sona Hoisington (Bloomington: Indiana University Press, 1988), 56-67, esp. 59.

3 Interestingly, it is Belinsky in his Eighth Article on Pushkin (1844) who defends Onegin against the incipient Tatiana cult. "The heart has its own laws," Belinsky writes, "Therefore, Onegin had a perfect right, without fearing the stern judgment of the critics, not to fall in love with the girl Tatyana and to fall in love with the woman. In neither case did he act morally or immorally... There is nothing dreamy or fantastic about Onegin. He could be happy or unhappy only in reality and through reality." See Vissarion Belinsky, "Eugene Onegin: An Encyclopedia of Russian Life," Russian Views of Pushkin's “Eugene Onegin,” 34, 40.

4 For a survey of the ebbs and flows in Tatiana's critical image (as of the early 1970s), see Geraldine Kelley, "The Characterization of Tat'jana in Puškin's 'Evgenij Onegin”" (Ph.D. dissertation, University of Wisconsin-Madison, 1976), esp. part 1. 
obvious stumbling blocks: for example, that Tatiana is assembled from imported sentimentalist scraps and yet, on the strength of one folkloreladen nightmare and a love of winter, represents the "Russian soul"; or that the moments of Tatiana's most profound transformation are concealed from us by the garrulous and possessive narrator. But there are also more radical discontinuities. Foremost among them is the hectoring, sententious and holier-than-thou tone that Tatiana adopts in her final rebuke to Evgeny in chapter 8: a lecture, as I shall suggest below, that Tatiana in all likelihood could never have delivered to Onegin in the form that Pushkin transcribes it. ${ }^{5}$ In this essay I suggest an alternative reading of Tatiana's role in the novel, one that acknowledges her extraordinary vigor and potency but makes it more aesthetic than moral, and-here's the blasphemous, counter-cultic rub - that sees this potency as largely Evgeny's achievement.

\section{Falling in love with Tatiana, four hypotheses}

All three creators in the novel (Pushkin, the narrator, and Evgeny in his capacity as title role) sooner or later come to love Tatiana, each for his own reasons. Although the courtships of these respective suitors are carried out on different planes and often overlap, the following motivations for Eros can be distinguished. First there is the "forbidden fruit" argument, largely associated, I would argue, with Evgeny's sphere. The narrator does not doubt

5 Among those critics who have found unpersuasive the final meeting between the lovestruck Onegin and Princess Tatiana, three will have special relevance for my reading: Nabokov, Little, and Gregg (see below). I lay aside Viktor Shklovsky's famous claim that the narrator's primary stance toward Tatiana throughout the novel - and in fact his stance toward plot in general - is parodic. Two factors suggest caution: (1) Tatiana (like all Pushkin's heroines after the mid-1820s) is smarter than the plots in which she finds herself and does not need the heavy hand of outside commentary to help her outgrow her setting; and (2) the early polemical Shklovsky tends to see parody everywhere; for him the work often serves to legitimate the device and not the other way around. See Viktor Shklovskij, "Pushkin and Sterne: Eugene Onegin" [1923], in Twentieth-Century Russian Literary Criticism, ed. Victor Erlich (New Haven: Yale University Press, 1975), 63-80. Shklovskian parody has corroded both hero and heroine. Consider a brief essay marking the 1937 Pushkin Jubilee by the émigré scholar Pyotr Bitsilli, who asserts that Tatiana, before and after, never understood Onegin, cast unfair aspersions on him at the end, and in fact "killed Onegin, turned him from a living human being into a 'laboratory animal,' a 'type' - and what she did with him, others have done with her" ("Smert' Evgeniia i Tatiana," Sovremennye zapiski 44 [Paris, 1937]: 413-16). 
its power, over the hero and over people in general, as he tells us in the famous lines from chapter 8 , xxvii:

Что вам дано, то не влечет,

Вас непрестанно змий зовет

К себе, к таинственному древу;

Запретный плод вам подавай,

А без того вам рай не рай.

[What's given to you does not entice,

The serpent calls you incessantly

To himself, to the mysterious tree;

The forbidden fruit must be offered you,

Without it, paradise does not seem paradise.]

We must remember who is offering this wisdom. Being deeply in love with Tatiana himself, the narrator has his own reasons for discounting the possibility of anything like genuine growth or spiritual commitment on the part of his rival Onegin - whose sudden passion for Tatiana he would prefer to fob off as perverse. But even so, we must admit that the forbiddenness of the Tatiana-Onegin bond always lent it enormous erotic energy. He likes her now because she is off limits; in the provinces she had been in the palm of his hand and so, in Byronic fashion, he had yawned and turned away. The portrait of Onegin back from his travels (8, xii-xiii) suggests that right up until the end of the novel, the pattern of his life - transitory stimulation and restlessness followed by renewed anesthetization - has not altered. Only illicit love will effect that change. Interestingly, both parties share this economy; Onegin's distanced unavailability had earlier fueled Tatiana's passion as well. As she put it in her fateful letter, she might have been satisfied with casual social contact but Onegin, being "neliudim" [unsociable], could be reached only in this covert, confessional, maximally risk-laden, epistolary way. The letter prematurely formalizes the terms, celebrates her helplessness, and heats up the terrain.

The dynamics of Tatiana's life remain in this covert zone. Richard Gregg has done a persuasive reading of her dream along these lines, interpreting its "phallic shapes," "priapic creatures" and shuddering, violent denouement as punishment self-imposed by Tatiana for her illicit desire. ${ }^{6}$ "It becomes

6 Richard A. Gregg, “Tat'yana's Two Dreams: The Unwanted Spouse and the Demonic Lover," Slavonic and East European Review 48 (1970): 492-505, esp. 502. 
clear," he writes, "why Ol'ga first breaks in on the would-be lovers; for her shallow, conventional, and well-advertised love differs from Tat'yana's deep, clandestine passion for the 'demonic' Onegin" (502). Both nanny and mother had been married off without love, the sister is en route to being married off without obstacle; neither of these options is, for the likes of Onegin or Tatiana, "paradise." They are destined to experience something deeper. «Погибнешь, милая», the narrator predicts, «но прежде / Ты в ослепительной надежде / Блаженство темное зовешь...» [You shall perish, my dear, but first in blinding hope you will summon forth dark bliss] $(3, \mathrm{xv})$. The prophecy is only a half-truth. That Tatiana does not perish, as do the ill-fated sentimental heroines Julie, Clarissa, and Delphine upon whom she modeled her life, is an issue to which we will return. For now, suffice it to note that throughout the novel, erotic interest between Tatiana and Evgeny is propelled forward by the clandestine and forbidden.

There is a second argument for falling in love with Tatiana, one associated with Pushkin as author. The 1820s, the decade of Evgenii Onegin, inclined Pushkin increasingly toward prose, toward national history, toward genealogy and family - and aggravated his anxieties over social status and rank. Compulsively attractive here for the mature Pushkin is the image of the married Tatiana as kniaginia [princess] and the chilling, elevating epithets she gains in this context: Pokoina. Vol'na. Ravnodushna. Smela. Nepristupnaia boginia roskoshnoi, tsarstvennoi Nevy [Calm. Unconstrained. Indifferent. Bold. Inaccessible goddess of the luxuriant, regal Neva] (8, xxiixxvii). It has been argued that placing Tatiana in very high society - so high that coquetry, a primary medium for the bachelor Pushkin, had no place at all («его не терпит высший свет» [highest society does not tolerate it] 8, xxxi) - was an act of wish fulfillment on Pushkin's part. Negotiating in 1829 to become a bridegroom himself, Pushkin desired to believe what was certainly contrary to his own high success at seducing other men's wives: that female constancy in marriage was possible. ${ }^{7}$ And then there was the poet's own social ambition. Douglas Clayton, one of Pushkin's best close readers, has suggested that the married Tatiana's graceful persona and accomplished social skills were a surrogate for her creator's personal fantasies. "Pushkin,

7 For a discussion of the evolving status of marriage as the novel progresses - from the site of open ridicule to the site of potential honor - see Leonore Schleffler, Das erotische Sujet in Puškins Dichtung (University of Tübingen, 1967), chap. 3, "Tat'jana Larina," 178-200. "Marriage is spoken of pejoratively in the first six chapters," Scheffler notes. "Only after the sixth chapter does the accent change... In the eighth book the subject is silently closed... [There,] Pushkin's initial irony about Tatiana is missing entirely" (194). 
the marginalized, the invalidated, the heretic... was metamorphosed into the heroine - not the hero - of his poem," he writes. "Her acceptance at court, her brilliance, her tenderness, passion, and conviction - all these were the qualities Pushkin sought for himself." ${ }^{8}$

Even without the poet's envy of his own heroine's fate, however, Tatiana as princess is a powerful external success. By the novel's end she has mastered what salon society of the early nineteenth century valued most of all: the ability to adapt oneself effortlessly to any appropriate role in the interest of social harmony. It is in this sense that William Mills Todd considers Tatiana's "cultural maturation" complete once she has become the hostess of a highly regarded Petersburg salon - which was, he reminds us, "the highest form of creativity open to a woman at this time," and one that enabled her to impose "what her age considered an aesthetic order upon reality."

Aesthetic considerations lead us to a third argument for falling in love with Tatiana, perhaps the most profound, this time identified with the narrator's persona. Unlike his friend Onegin, the narrator is a poet. But unlike the poet Pushkin, whose stylized image he represents, the narrator can be garrulous, inefficient, sentimental. As befits a "novelist" (even a novelist writing in verse), the narrator might be understood as embodying some aspects of Pushkin at the turn of the decade, a poet on the brink of turning to prose, since the novel, as we know from Pushkin's famous quip to Bestuzhev, requires above all boltovnia [chatter]. The unity of this narrator's voice throughout the nine years of Onegin's genesis is problematic. ${ }^{10}$ On one point, however, the narrator is unflaggingly constant, and that is his love of Tatiana. From her initial introduction onward, she is revered as something untranslatable, as a quality that cannot be completely transmitted, as that which inspires us but that eludes precise description. The narrator refers to this elusive presence as his Muse. We first hear of this Muse - who grants a voice to the poet only after the storm of love has passed - at the end

8 J. Douglas Clayton, "Towards a Feminist Reading of Evgenii Onegin," Canadian Slavonic Papers 29 (1987): 255-65, esp. 261. See also Clayton's Ice and Flame: Aleksandr Pushkin's "Eugene Onegin" (Toronto: University of Toronto Press, 1985), chap. 1, "Criticism of Eugene Onegin" (7-71, esp. 57), for a sociobiographical Soviet explanation of the mature Tatiana that combines both spousal and aristocratic motifs.

9 William Mills Todd III, Fiction and Society in the Age of Pushkin: Ideology, Institutions, and Narrative (Cambridge, MA: Harvard University Press, 1986), 129 [in chap. 3 on Eugene Onegin]; see also chap. 1, "A Russian Ideology."

10 See J. Thomas Shaw, “The Problem of Unity of Author-Narrator's Stance in Puškin's Evgenij Onegin," Russian Language Journal 35 (1980): 25-42. 
of chapter 1 . At the beginning of chapter 8 she is personified, identified with a chronological sequence of Pushkin's literary heroines, and finally "presented" to Petersburg society in a gesture coterminous with Tatiana's coming-of-age in the salon. How does the narrator present Tatiana as both beloved subject and Muse?

We first meet Tatiana in chapter 2. One of the more remarkable aspects of her opening portrait, surely, is how little of it there is. In her initial description, negatives abound: «Ни красотой сестрой своей, / Ни свежестью ее румяной / Не привекла б она очей» [Neither with her sister's beauty nor rosy freshness would she attract anyone's eye] (2, xxv). Unlike the heroines of her sentimental novels, and unlike Olga, Lensky, and Onegin in Pushkin's novel, Tatiana is endowed by the narrator with no precise physical attributes: no colors, clothes, supporting equipment, musical or domestic activities (we assume she is dark because her sister is blonde). From early childhood on, Tatiana's prime characteristic has been a detachment from her surroundings. She had not snuggled up to father or mother; she had not frolicked with the other children; she had not played with dolls or shown interest in news or fashion. She has deep feelings; but in contrast to the heroines of her favorite books, she is not in the habit of using these feelings to manipulate the behavior of others. She does not swoon or faint, weep in public, pray noisily, or interact commodiously with the world. ${ }^{11}$ Tatiana, we might say, attaches to the inside and not to the outside of things.

This "insideness" and inaccessability continue to characterize Tatiana even at her most exposed moments, and for this we must thank her jealous mentor and most passionate protector, the narrator. He filters out large parts of her life, keeps them for himself, and gives them to us only in translation. Tatiana's love letter to Onegin is originally in French but we only see its cooled-down Russian version (whereas Onegin's letter, by contrast, is immediately in the public domain - for who cares, here it is, "toch'-v-toch" [word for word]). After Tatiana moves from country to city and becomes a princess, we sense she has become some marvelous thing. But the narrator cannot find Russian words to describe her: she is "comme il faut," "not vulgar" $(8, \mathrm{xiv}, \mathrm{xv})$, and these foreign words convey not so much a physical image as

11 For a discussion of Tatiana's reduced "portraiture" and her patterns of detachment and non-interaction, see Kelley, part 1, "Narrated Characterization," esp. 27-57. Also significant, I believe, is the haunting quasi-representational sketch of a kneeling female figure (front or back? clothed or nude?) on an 1824 rough draft of Tatiana's letter to Onegin (reproduced in Clayton, Ice and Flame, 137). 
a mode of behavior, a sense of ever present appropriateness, of not doing anything awkwardly or wrong. Like the veil draped over the face of a harem favorite, they conceal from casual passers-by the essential positive thing. For this the narrator disingenuously apologizes: «Не знаю, как перевести ...Не могу» [I don't how how to translate it... I can't].

Indeed, he must not translate her. Tatiana sits by the window, waits, watches, and perceives; the narrator only rarely makes us privy to her thoughts. I would argue that he cannot do so, for Tatiana is poetic inspiration - which, according to Pushkin's own inspired definition, is neither an ecstatic outpouring of feeling nor a fixed accomplishment but something more intimate, private, disciplined, and creative: a cognitive receptivity of the mind to potentials. Or as the poet drily put it: inspiration is a "disposition of the soul to the most lively reception of impressions and thus to a rapid grasp of concepts that facilitate explaining them."12 Tatiana takes in, understands and orders impressions, but (except for the single very large instance of her passionate letter) does not spend. And thus the fourth hypothesis: that as readers we love Tatiana because she represents the energy (and knowledge) captured in a certain sort of poetry.

\section{Tatiana as synaesthesis}

"It is the essential privilege of beauty," Santayana writes, "to so synthesize and bring to a focus the various impulses of the self, so to suspend them to a single image, that a great peace falls upon that perturbed kingdom."13 The Tatiana of chapter 8 has just such an effect on the boisterous tempo and restless variety of Evgenii Onegin — if not on its aroused and bewildered hero - and it is her unexpectedly abrupt departure that brings the novel to an end. How might we understand Tatiana's spiritual economy? Admittedly the heroine of a novel, she is also and crucially a heroine in verse; and as such

12 Pushkin is responding here (in unpublished draft) to an 1824 article in Mnemozina by his friend Vilgelm Kyukhelbeker, in which the author declared "strength, freedom and inspiration" essential to all true poetry and identified inspiration with ecstasy [vostorg]; Pushkin disagreed. See Carl R Proffer, ed. and trans., The Critical Prose of Alexander Pushkin (Bloomington: Indiana University Press, 1969), 52.

13 George Santayana, The Sense of Beauty (New York, 1896), 235-36, as cited in William K. Wimsatt and Cleanth Brooks, Literary Criticism, A Short History (Chicago: University of Chicago Press, 1957), 2:618-19, in the chapter "I. A. Richards: A Poetics of Tension," an excellent survey and critique of Richards's aesthetic positions. 
she is more, I suggest, than the mere sum of her personality and plot. She is also an aesthetics.

The Romantic period knew various Dionysian theories of poetry: as emotive release, as madness, as divine spontaneity. But there were countervailing views as well, which understood poetry either as that residuum following the moment of rapture (Wordsworth's celebrated formula, a "spontaneous overflow of feelings recollected in tranquillity," shared by Pushkin's narrator in Onegin) or, more conservatively, as something akin to passion under constraint, to a "pattern of resolved stresses." With his strong neoclassical inclinations, Pushkin certainly would have been attracted to such a "poetics of tension." In more recent times, the thinker who has given most elegant expression to this aesthetic is the English analytical critic and poet I. A. Richards.

In Richards's view there are two fundamentally different types of poems, based on the two ways in which impulses may be organized: by inclusion (synaesthesis) or by exclusion. ${ }^{14}$ The most powerful and stable poems - the ones least vulnerable to disruption though irony-belong to the former synaesthetic category; that is, they sustain a maximally large number of opposed, heterogeneous impulses in meticulous balance. Associations then form between "stable poises," which enable and constitute memory. ${ }^{15}$ Such verbal art is profoundly enabling, but in a special, aesthetically disinterested, almost architectural way. We begin to see "all around" things, in larger and more serene context, for "the less any one particular interest is indispensable, the more detached our attitude becomes... One thing only perhaps is certain; what happens is the exact opposite to a deadlock, for compared to the experience of great poetry every other state of mind is one of bafflement" (Richards, Principles, 252).

14 I. A. Richards, Principles of Literary Criticism (New York: Harcourt, Brace and World, 1925), chap. 32, “The Imagination," 239-53, esp. 249-52. Richards's comments on the relative value of emotions (of lesser import) and attitudes (of greater) for any given experience recall Pushkin's distinction between ecstasy and genuine inspiration: "It is not the intensity of the conscious experience, its thrill, its pleasure or its poignancy which gives it value," Richards writes, "but the organization of its impulses for freedom and fullness of life. There are plenty of ecstatic instants which are valueless" (132).

"Imagine," Richards writes in chap. 14, "an energy system of prodigious complexity and extreme delicacy of organization which has an indefinitely large number of stable poises. Imagine it thrown from one poise to another with great facility, each poise being the resultant of all the energies of the system... Such a system would exhibit the phenomenon of memory: but it would keep no records though appearing to do so. The appearance would be due merely to the extreme accuracy and sensitiveness of the system and the delicacy of its balances" (104). 
It could be argued that Tatiana functions at the end of the novel as a tension-filled, painstakingly balanced, stable and harrowingly lucid synaesthetic poem. Can such an analogy help us understand her ultimately dazzling effect on Onegin, the inveterate prosaicist who comes to read her most passionately? Several obvious factors mark her as a synaesthetic Muse: her autonomy and detachment from her immediate surroundings, her literariness, the tenacity of her memory, the vivid inwardness of her imagination. (In an intriguing supplementary analogy from acoustics, Tatiana and the type of poetic tension she represents might be seen as a "standing wave," a complex resolution of internal antagonisms occurring within a closed air column or along a plucked or vibrating string that only incidentally, and as part of its own inner task, radiates energy in the form of music to the outside world.) ${ }^{16}$ After the initial "pluck" or impact of Evgeny, Tatiana's tensions in matters of love are essentially self-generated, independent of further outside event. This self-absorption and stasis is crucial to the stability of her image.

Much work has been done, for example, on the specific textual links between Tatiana and the heroines she adores: Rousseau's Julie, Richardson's Clarissa. ${ }^{17}$ But we should note that Pushkin's love-smitten heroine employs these borrowed motifs in her letter quite without cause. As one chronicler of Tatiana's fate has sensibly remarked, Rousseau's Julie appeals to St. Preux's honor in trying to fend off his amorous advances, but "Tat'jana is not in need of defense from Onegin's passions." ${ }^{18}$ Onegin has given her no real-life grounds

16 A transverse standing wave develops between two fixed nodes when a direct wave, the result of a shock, pluck, or other impact, comes to be superimposed in one direction upon its reflection going the other way. Within this column, troughs and crests pulsating at regular intervals generate a complex matrix of fundamentals, partials, and harmonics. Curiously productive in this acoustic analogy is the degree of inner concentration required to resolve these antagonisms, and the fact that a byproduct of this resolution is an exquisite "radiation" of sound - much more complex than can be appreciated by our hearing apparatus, which distorts and orders the escaping aural energy to serve its own, rather primitive "communicative" purpose. The wave itself, wholly occupied by its internal economy, is indifferent to any music-making effect it might have on the air outside. I thank my father, David Geppert (Theory Department of the Eastman School of Music, now retired), for this suggestive analogy with Tatiana's aesthetics.

17 See Leon Stilman, "Problemy literaturnykh žanrov i tradicij v 'Evgenii Onegine’ Puškina," in American Contributions to the Fourth International Congress of Slavists (The Hague: Mouton, 1958), 321-67; Michael R. Katz, "Love and Marriage in Pushkin's Evgeny Onegin," in Oxford Slavonic Papers, ed. J. L. I. Fennell and I. P. Foote, n.s., 17 (Oxford: Clarendon Press, 1984), 77-89; and Stanley Mitchell, “Tatiana's Reading," Forum for Modern Language Studies 4 (1968): 1-21.

18 See Kelley, “Narrated Characterization," 129-30. 
for considering him, even potentially, a "kovarnyi iskusitel" [treacherous tempter]. ${ }^{19}$ If anyone tempts in this novel, it is Tatiana herself: as she well knows, she is the one who oversteps the bounds and presents this near stranger with premature options (guardian angel, seducer). ${ }^{20}$ Such an understanding of Tatiana's autonomous, already wholly formed love, for which she takes full and anguished responsibility, lends support to John Garrard's point that in the famous triad of Tatiana's literary prototypes - "Clarissa, Julia, Delphine" $(3, \mathrm{xi})$ - the "Yuliia" in question is not Rousseau's sentimental and lachrymose Julie but rather the "Donna Julia" of canto 1 of Byron's Don Juan. ${ }^{21}$ Donna Julia is an emotionally experienced woman, deeply marked by her passionate and ill-fated love for the immature Juan. After the scandal is discovered and she has been immured in a convent, she writes him a stunning letter of love and renunciation that the poor adolescent boy can hardly comprehend.

Let us pursue this Byronic subtext. "Man's love is of his life a thing apart, / 'Tis woman's whole existence.../ And so farewell-forgive me, love me - no, / That word is idle now, but let it go" (canto 1, 194-95): these famous lines from Donna Julia's letter to Don Juan do indeed suggest the same intoxicating mix of active passion, resignation, surrender, memory of the past and reconciliation with the present that so resonates in Tatiana's final high-minded scene with Onegin. ${ }^{22}$ But viewed from within the economy of

19 In Tatiana's defense I cite Richard Gregg, who was generous enough to give this essay a compassionate reading containing this insight: "One could argue that Onegin is for Tatiana a kovarnyi iskusitel' in the same way that a shot of bourbon is for an alcoholic. The liquor is, ethically speaking, innocent. But it treacherously tempts all the same."

20 There have been attempts to soften Onegin's "rejection" of Tatiana's ill-timed suit, for example by Ludolf Muller in "Tat'janas Traum": the snowy landscape is read as Tatiana's lonely, internal pre-love state; the accommodating bear as sexuality (the "dark drive of love" that will release her from loneliness); Onegin himself as the one human figure who can tame the frightening ogres that inhabit the hut of potential erotic life; but "the marriage is not consummated. A lack of interest on Onegin's part is not to blame: we saw that in the depth of his being he indeed loves her, and that a longer, well-intentioned neighborly contact could have awakened this seed of love within him." See Ludolf Muller, “Tat'janas Traum," Der Welt der Slaven 7 (1962): 387-94, esp. 393.

21 John Garrard, "Corresponding Heroines in Don Juan and Yevgeny Onegin" [1993], unpublished ms. Garrard notes that Amedée Pichot's French prose translation of Don Juan softened Byron's sarcasm and helped move the focus of the text to Julia; he also notes that the episode of Julia's letter is one of the very few patches of Byron's text free of corrosive narrative irony (a tone Pushkin disliked, and that his own narrator completely drops in chapter 8).

22 Stephanie Sandler has provided the best reading of chapter 8 and of the entire novel as a "text of renunciation and a text of continuing attraction." See her Distant Pleasures: Alexander Pushkin and the Writing of Exile (Stanford: Stanford University Press, 1989), esp. 207. 
a synaesthetic poem, one that balances opposing tensions but does not spend, this is renunciation only in a special sense. It must not be understood wholly as sacrifice or personal loss. Tatiana herself does not indulge in explanations, as Byron does for his Donna Julia and as Tatiana's sentimentalist predecessors most assuredly would have done. She does not motivate or justify her action beyond her one efficient statement to Evgeny, and the frame surrounding her final monologue is stripped of almost all narrative commentary. She simply departs. And just as we must not read Tatiana backward to those over-determined eighteenth-century heroines, so must we resist reading her forward. It is a mistake, I submit, to see in Tatiana a realistic heroine out of Turgenev or Tolstoy, a woman with a strictly biographical fate and fully psychologized significance.

Some highly unorthodox implications will be eased out of this idea at the end of this essay; but now to return to the mature Tatiana as Muse. I suggest that she be appreciated not as tragic heroine or renunciatory object but as a special sort of dynamic poetic principle, authoritative because of its lucidity, its ability to maintain all its parts intact under pressure, and its willingness not to spend impulsively merely to resolve the external, overtly manifest plot. This reading shares some terrain with the intriguing hypothesis put forth by the great Soviet developmental psychologist Lev Vygotsky, whose chapter 10 of his youthful treatise The Psychology of Art contains a provocative reading of Evgenii Onegin. ${ }^{23}$ Because, Vygotsky argues, we are predisposed to assume static protagonists in this tightly spinning verse tale, Pushkin easily confounds us with his misleading symmetries. All the loves, love letters, and parallel confrontations that so neatly mirror one another distract us from the possibility that both hero and heroine have genuinely matured by the end of the novel. Vygotsky takes seriously the dozen or so questions that crowd into stanzas vii and viii of chapter 8: "Is it really Onegin? Could it be him? Is he the same or has he changed? What's he like now? Do you recognize him? Yes and no..." (ellipsis in original). These questions matter, Vygotsky intimates, because real inner change is never perfectly transcribable

L. S. Vygotskii, Psikhologiia iskusstva [1925] (Moscow: Iskusstvo, 1968), 282-88: in English, Lev Semenovich Vygotsky, The Psychology of Art (Cambridge, MA: MIT Press, 1971), 222-28. In chapter 9, "Art as Catharsis," Vygotsky expresses dissatisfaction with most explanations of aesthetic response because they ignore a theory of the imagination and a theory of real-life emotions - two components that always interact in our response to art, which is why artistic effect is so much more than an "illusion." Such theories are difficult to come by, he admits, because critics (unlike his sort of psychologist) work at the level of analysis; they have no direct access to primary artistic synthesis. 
on the outside. In the first half of the novel, so taken up with descriptions of Onegin's cluttered, thing-packed life, the narrator does indeed give the illusion of biographical transcribability - but that is because on both sides, love begins as an artificed construct. Onegin is defined as "the sort of person who cannot be the victim of a tragic love," Tatiana as the maiden who falls in love with a fabrication of her own devising and thus must perish. But then, Vygotsky argues, "Pushkin develops the story against the grain of the material." He introduces genuine drama - which, unlike the expected, fixed outcomes of sentimentalism or tragedy, is always open. According to Vygotsky, the greatest art always prepares us for this sort of catharsis. What we see in great dramatic art is only one provisional resolution; and the more lucid and lighthearted this resolution is, the more it bespeaks a plurality of other possible resolutions swarming underneath. Vygotsky claims that Pushkin's poetry always contains at least two contradictory feelings; when these opposing impulses collide, we experience aesthetic delight. ${ }^{24}$

\section{The ending: perhaps it didn't happen?}

The final portion of this essay will be undertaken in Vygotsky's developmental spirit. Throughout Evgenii Onegin, the narrator sings the praises of the perfectly calibrated and predictable life: «Блажен, кто смолоду был молод / Блажен, кто вовремя созрел» [Blessed is he who is young in his youth / Blessed is he who matures at the right time] $(8, \mathrm{x})$. The advice is apt, for the plot of the novel is one massive demonstration of the unblissful effects of ill-timed growth and missed opportunity. But juxtaposed to this value is a corollary that celebrates open, uncertain process: the magic crystal and the "free novel" only dimly discerned in it. These two values are best focused in the conflict between Onegin's letter to Tatiana and her excruciatingly delayed response, which brings him to her feet.

Tatiana in that final encounter is perfect control and passionate constraint. Whatever she means, she will not spend that meaning in the present tense of the novel; when she leaves, she carries that energy poised within her. In contrast, surely one of the more discrediting aspects of Onegin's lovesick letter is that he now spends extravagantly. He has

24 In his final book, Yuri Lotman discusses Pushkin's concept of inspiration precisely in terms of such collisions: see his Kul'tura i vzryv [Culture and explosion] (Moscow: Gnozis, 1992), 35-43, and especially the book's final chapter, "The Phenomenon of Art." 
collapsed entirely into the present, which must hold the promise of her presence, «Я утром должен быть уверен / Что с вами днем увижусь я» [In the morning I must be assured that I will see you later in the day]. Evgeny now imagines his life desperately closed down. As if recalling the narrator's warning - «Но жалок тот, кто все предвидит» [Pitiable is he who foresees everything] (4, li) - Onegin opens his letter to Tatiana on a hopeless note: «Предвижу все» [I foresee everything] (8, xxxii). We recall how he had facilely predicted disaster for marriage in his initial remonstration with Tatiana over her letter; now he sees the grim side of just such an approach to life, so unavailable for surprise or renewal. It is not that Onegin is dishonest. Quite the contrary: as several critics have noted and as I remarked above, in his own letter to Tatiana, Onegin is more conscientious at recalling their shared past than is Tatiana in her reconstruction of events during their final accounting. Onegin is honest enough; his problem is that he has lost all control over time, all sense of time's richness and unpredictability, and he is thus unable to displace or contain himself. At just this point the narrator pulls out abruptly, without having sealed the plot with a marriage or a death (as Pushkin's friends complained), with Tatiana fully contained and Onegin wholly vulnerable. Such elegant reversals and symmetries have encouraged some astute Pushkinists to see in Onegin a variant of the Echo and Narcissus myth. ${ }^{25}$ But if process-narratives and Pushkin's own capriciously parodic practice urge us to anything, it would be to distrust the absolute illusion of the mirror. Is there any way that this poetically symmetrical ending might be opened up into the hopeful, linear type of narrative, kaleidoscopically complicated and strewn with potentials, that the "magic crystal" of this novel appears to value so highly?

In response to that question, let us pursue an alternative reading of chapter 8. Taking our cue from its opening digression (also a belated introduction), this final chapter will be about the Muse, and how the poetnarrator glimpsed her image - radiant, volatile, caressing, sauvage - at crucial moments in his life. Apprehensively, the narrator now brings his Muse for the first time «на светский раут» [into high society] (8, vi). But in her ultimate embodiment she is no cause for apprehension; respectful of

25 See Riccardo Picchio, "Dante and J. Malfilâtre as Literary Sources of Tat'jana's Erotic Dream (Notes on the Third Chapter of Puškin's Evgenij Onegin)," in Alexander Puškin: A Symposium on the 175th Anniversary of his Birth, ed. Andrej Kodjak and Kiril Taranovsky (New York: New York University Press, 1976), 42-55; and more recently Marina Woronzoff (Yale University), "The Tale of Echo and Narcissus, Retold: Pushkin's Tatjana and Eugene," paper delivered at AATSEEL Annual Meeting, Toronto, December 1993. 
hierarchy and order, she has mastered the decorum of the salon and works flawlessly within it. ${ }^{26}$ The Muse is Tatiana, and this is her final enabling transfiguration.

And Onegin? He has always been more aggressively stubborn and contrary, yawning where he should applaud, foreseeing everything, opposing himself to poets. Having suffered this extraordinary, inexplicable onset of love, he is at first totally without mechanisms for processing its effects. But the sequence of his reawakening is worth noting. Whereas before he had reflected his own exquisite image in various mirrors, reacted trivially to events, attended little or not at all to memory, and distracted himself at life's various feasts, now his past begins to align itself in answerable patterns and thus to haunt him. His attempts to confess this inner shift to Tatiana are rebuffed. As a man who had always preferred the fashionable closed forms of disillusionment and despair, how convenient it would be to act out the romantic hero who can spend recklessly, throw himself at his beloved's mercy and be done with it; then he might return to that familiar state where, once again, events begin boisterously, end tediously, and life holds no secrets because always «хандра ждала его на страже» [spleen lay in wait for him] (2, liv). But if Tatiana as provincial maiden was susceptible to such Byronic posturing, Tatiana as mature, creative Muse is indifferent to this indulgence. She now contains her energy like a standing wave, composed and resonant, and is no longer needful of outside provocation. Onegin seeks signs of confusion, compassion, some trace of tears on her face, but detects nothing: «Их нет, их нет!» [There aren't any, aren't any!] (8, xxxiii). Eerily, Onegin begins to "tune himself" to Tatiana, to duplicate her trajectory in the novel. He withdraws, grows pale, begins to read obsessively. But he cannot keep her at bay; in her realm - a realm that absorbs and reworks rather than reflects - memory is born; Evgeny's past begins to intrude, he is forced to come to terms with the trivial and violent acts of his youth; and as backdrop to this birth of a responsible biography, between the lines of his reading

26 Here one might supplement Yuri Lotman's gloss on chapter 8, VII, 1-4, in which he appears almost to apologize for Tatiana's tolerance of the "structured order and mix of ranks and ages" in the aristocratic salon (in Iu. M. Lotman, Roman A. S. Pushkina "Evgenii Onegin": Kommentarii [Leningrad: Prosveshchenie, 1980], 346-49). Lotman assures his readers that such an "affirmative assessment of high society" from a heroine representing Russian national virtues indeed rings oddly in a novel that contains so much social satire. But if we assume, as in my reading Pushkin invites us to do, that Tatiana is the spirit not of Russian virtues but of poetry, then nothing could be more appropriate for this hybrid novel-in-verse than admiration for "structured order and mixed rank." 
he sees a country house, «И у окна / Сидит она...и все она!» [And at the window she sits... always she!] (8, xxxvii).

Against the grain of most readings of the final chapter, I suggest that at this point in the novel all real interaction between the hero and heroine ends. To be sure; Evgeny «не сделался поэтом, / Не умер, не сошел с ума» [did not become a poet, did not die, did not go out of his mind] (8, xxxix). But the winter was not an easy one. Unable to settle accounts with the past or project a future because of the unforgiving needs of his present, driven to despair by Tatiana's nonresponsiveness and stimulated by a season of indiscriminate reading, Onegin commits the only act that can bring about a permanent present tense in his life: he fantasizes his final visit. The strangeness of that sudden visitation has long been noted by critics. ${ }^{27}$ The speed with which Evgeny moves through the city toward his beloved; the uncanny absence of any domestics at the door or in the halls of the Prince's house; the extraordinary ease with which Evgeny gains access to Tatiana's boudoir - all this has been interpreted variously as dreamlike activity, fairy-tale logic, or the narrator's gentle irony. Indeed, hints of dream space prefigure Evgeny's infatuation. In chapter 8, immediately after his glimpse of Princess Tatiana, he thinks: "That girl... or is it a dream?" (xxx; ellipsis in original); and later, Evgeny's "sleep [son] is disturbed by fantasies [mechtoi] now melancholy, now charming" (xxi). ${ }^{28}$ But as we approach the final decisive tête-à-tête, we come upon many more fantastical and fantasizing details that signify a more substantial phase change, not only in the hero but in the larger narration as well.

The first thirty-five stanzas of chapter 8, and especially the elegiac, quasiautobiographical digression on the Muse that opens the chapter, are almost

27 See, for example, T. E. Little: “Onegin's journey through Petersburg has a dreamlike quality about it... [His] entry into Tatyana's house resembles the entry of a fairy tale prince into an enchanted castle. He meets no servants; the house appears to be empty." T. E. Little, "Pushkin's Tatyana and Onegin: A Study in Irony," New Zealand Slavonic Journal, no. 1 (1975): 19-28, esp. 21.

28 In his survey of dreams in Pushkin, Michael Katz notes the "proliferation of dreams and dreamers in Eugene Onegin," concluding that Tatyana reconciles herself to the results of her choice and station whereas "Onegin remains a slave to his dreams [mechty] and is completely unable to accept the realities of life. Therefore she must reject him." See Michael R. Katz, "Dreams in Pushkin," California Slavic Studies 2 (Berkeley and Los Angeles: University of California Press, 1980), 71-103, esp. 92 and 99. In my reading, Tatyana is indeed reconciled to her fate, or perhaps even embraces it - but it is precisely Onegin's realization of this irreversible fact that triggers in him his ultimate mechta or fantasy-dream of their final intimate scene. 
entirely free of the narrator's ironic, undercutting banter. Now that tone is back, jostling Onegin, "moi neispravlennyi chudak" [my unreformed eccentric] and making asides to the reader at his expense: «Куда.../ стремит Онегин? Вы заране угадали; точно так» [You've already guessed / where Onegin is rushing; precisely] (8, xxxix-xl). At an ominously rapid pace, the narrative begins to resemble erlebte Rede or inner speech: "He was hurrying to her, to his Tatiana" [k svoei Tat'iane] - since when is she "his"? Only in the reality of his own longing. Unseen by anyone, he slips into her private rooms; it is, after all, a mental journey that he has now been rehearsing for months. But two conditions must obtain before the creative inner fantasy can begin to unfold in earnest. First, Onegin must reassure himself that Tatiana cares for him, that she spends the same obsessive time over his image that he has spent over hers, that she weeps (albeit in private) and that there are traces of "confusion, compassion and tears" on her face. Second, he must be persuaded that time is reversible.

The second condition is held in suspension: Is princess Tatiana in fact still the "prezhniaia Tania" [former Tania] of earlier years, and can that image be recovered? Until the very end of the scene, the reader is not allowed to know. The first condition, however, is easy to imagine and is immediately supplied. It is the stock-in-trade device of the beloved woman accidentally discovered, alone, "neubrana," "bledna" [not yet made up, pale], shedding tears over passionate letters sent her by her repentant lover. (Pushkin will use this device to lovely comic effect in "Baryshnia-krest'ianka" [The Young Lady-Peasant], the last and most festive of his Belkin Tales.) Tatiana does not cast Evgeny away, but neither does she urge him on; she is as impassive as a shade. In this intense and static scene, what does Evgeny seek? He is still no poet; he will not be granted a poetic Muse. But Tatiana is available to him, I suggest, as inner conscience, and it is this voice that is internalized in him and matures in her presence.

Interpretations of Tatiana as Onegin's "fatum," as "the tangible expression of the weight of his conscience," are not new in the literature on this final scene. ${ }^{29}$ But such readings assume that the Tatiana of this scene is real; it is only Evgeny's conscience and the quality of his love that might be fraudulent. I argue the opposite case here: that precisely because Evgeny's love and suffering are real, because there has been this genuine, inexplicable change in him brought about by - who knows? - the passage of time, or the onset of true love, Tatiana does not need to be physically present. She can 
be conjured up, which is, after all, the proper ontological state for an ethical Muse. Nowhere in his drafts or variants for chapter 8 does Pushkin suggest that such was his intention. But we do know that Pushkin worried over the ending of his novel and experimented with various means for deepening the reader's knowledge of the hero, including a travel diary and a salon album, both ultimately abandoned. As Leslie O'Bell chronicles the novel's composition: "It was the razvjazka or resolution that came hard... The Journey and the Album, like the sequence in Onegin's Library, were both devices for the self-revelation of the hero." ${ }^{30}$ I suggest here that Tatiana's crowning lecture to Onegin can be read in precisely this way, as a "selfrevelation of the hero."

Astute readers have long expressed dissatisfaction with this final encounter. Vladimir Nabokov, arguing against the mass of "passionately patriotic eulogies of Tatiana's virtue," insists that her altruistic rejection of Onegin is simply a cliché of French, English, and German romantic novels; what is more, "her answer to Onegin does not at all ring with such dignified finality as commentators have supposed it to do." ${ }^{11}$ More radically, T. E. Little urges us to take the entire love relation between Tatiana and Onegin as ironic from the start: Tatiana's silence might well be due neither to moral strength nor clandestine pining but simply to indifference or disgust. The ending scenario, where "sentimental heroine meets a reconstructed Byronic hero," is simply "a typical Pushkinian jest" in which Tatiana mercilessly teases her victim. ${ }^{32}$ Richard Gregg, turning from the form to the content of Tatiana's final monologue, finds in it a dozen inaccuracies, or, more kindly, subjectively emotional opinions on Tatiana's part that unfairly slander Evgeny. ${ }^{33}$ Such

Leslie O'Bell, “Through the Magic Crystal to Eugene Onegin," in Puškin Today, ed. David M. Bethea (Bloomington: Indiana University Press, 1993), 152-70, esp. 164-65.

31 Aleksandr Pushkin, Eugene Onegin, trans. Vladimir Nabokov, vol. 2 [Commentary and Index]' part 2 (Princeton: Princeton University Press, 1975), 241.

32 T. E. Little, "Pushkin's Tatyana and Onegin: A Study in Irony," 19-28.

33 See Richard Gregg, "Rhetoric in Tat'jana's Last Speech: The Camouflage that Reveals," Slavic and East European Journal 25 (1981): 1-12, esp. 1 and 6. Although mightily bothered by this speech, Gregg does not draw my radical conclusions. He restricts himself to ascribing Tatiana's indiscretions to rhetorical devices and an emotional loss of control, asking "to what extent do her remarks square with the facts?" while noting that "sincerity is, after all, no guarantee of veracity," and to asserting that although "Tat'jana cannot lie" (why not? Is Gregg under influence of the cult?), "in one crucial area of her experience she is an exceedingly unreliable witness." Kindly reacting to a draft version of this essay, Gregg responded thus to this inquiry of mine: "EMERSON: 'Is Gregg under the influence of the cult?' GREGG: 'Yup." 
verdicts are justly motivated by a sense that something is awry in this final scene. But to my mind they unjustly trivialize both parties - and especially the hero.

Gregg is certainly correct that Tatiana's memory is faulty and her tone with Evgeny gratingly abrupt. I would go further: her tone is almost male, as if this painful but necessary denouement had to begin with Evgeny addressing a portion of his own self. In my scenario, of course, he is. (Tatiana refers to him throughout as "Onegin," the way men do to one another, the way Evgeny did with Lensky). In fact, much of what she says to him makes better sense if understood self-referentially, as confession. Tatiana rejects Onegin - just as his inner self, now more sensitively attuned and responsible to its own past, knows that she must. If Tatiana now remembers "only severity" [odnu surovost'] in Onegin's reaction to her letter and reproaches him for his "cold glance" and "sermon," we know that this misrepresents his actual tone and tenderness on that day. Under present conditions, however, Onegin quite forgivably desires to punish himself for having let something pass him by then that is now so utterly indispensable to him. Onegin also knows in his heart (and thus Tatiana makes the point to him explicitly and repeatedly) that at crucial moments in their unsynchronized courtship he had indeed acted honorably, given what he was and what he knew about himself at the time.

Tatiana's final speech is peculiar in other ways. Measured against the one anguished and hopelessly smitten letter of Evgeny's we are shown in the text, Tatiana's response is capricious, harsh, and explicit in ways that would appear unseemly for a woman of her tact and station. Although Evgeny does indeed have erotic designs on her person, Tatiana gives him very little quarter (that is, for a woman in love, as she claims she is); she insinuates that he loves her now primarily because she is rich, noble, close to the court, married to a battlescarred older man of princely rank, and that this love could only serve to bring shame upon her and "scandalously alluring fame" [soblaznitel'naia chest'] to him. Again, where such aggressive candor might seem inappropriate from the tactful, superbly disciplined Tatiana (even if temporarily reverted to her more innocent rural self), Evgeny, freshly burdened with a conscience about his past, could easily have had such shameful suspicions about himself, and might wish to exacerbate them in a punitive gesture of self-castigation. One of the final monologue's most oft-quoted lines - «и счастье было так возможно, так близко» [and happiness was so possible, so close] (8, xlvii) — is, logically speaking, only something that Evgeny could say. In that now-distant time, lest we forget, it was only for him, who held all the male rights to initiative in these matters, that "happiness was close and possible." From the very first 
line of her desperate love letter, Tatiana had been always in a state of risk, shame, and premature intimacy. In Tatiana's final speech, however, love is no longer the primary value. Gone is that simple Byronic sentiment, the pivot of every woman's "whole existence." The recurring themes now are those male virtues so precious to Pushkin himself: upriamstvo [stubbornness], gordost' [pride], chest' [honor].

When Tatiana rises and leaves the room, Evgeny feels "kak budto gromom porazhen" [as if struck by thunder]. Usual readings of this denouement admit of irony, of Evgeny's shock at Tatiana's moral excellence, at her self-control, at the sound of her husband's approach and the painful ridiculousness of his position. In the present fantasized context, however, the thunderbolt could be one of realization and internal growth. No wonder Evgeny is impressed at her speech. It belongs to him, to his own better self, to his conscience (the Muse now speaking from within, available for inspiration and moral orientation). Evgeny is still no poet, in the sense that Lensky and the narrator are poets. But the ideal inner companion that Tatiana had become for him could serve many purposes.

And here we might speculate on the end of Onegin in the context of Pushkin's own creative biography. By 1829 Pushkin himself had begun to investigate other, more prosaically grounded muses. These included the muse of prose, of history, perhaps of his own imminent marriage. Common to all — and here we should recall the second condition that Onegin longed for in his fantasy with Tatiana, the one that was not granted him - is the realization that time is irreversible. The hero of reversible time had been the chameleon-like "salon pretender" of the mid-1820s, epitomized by the flexible, carefree Dmitry Samozvanets, an adventurer whose many masks were all equally authentic and for whom the search for a "real self" would have been utterly inappropriate. Eventually, this "reversible" pretender would be replaced in Pushkin's creative imagination by the infinitely more serious one-way pretendership of Pugachev, for whom risks were high and historical responsibility was real.

Evgenii Onegin presages this shift. When Tatiana walks out, Evgeny is left with an irreversibly needful self that feels the weight of events in time. On one level, perhaps, the General's clanking spurs on the threshold presage scandal, duel, dishonor. But that scenario was tediously familiar, the old masks. Here was something new: both Onegin and the reader look up with that sinking, anguished feeling that comes upon us when we are caught "in the act" in the middle of a necessary, deeply private, partly illicit conversation with a beloved and loving voice, whose intimations of truth about ourselves we have only begun to summon up the courage to confront. 
Whither Tatiana? Contrary to the teachings of Belinsky (with whom the critical history of Evgenii Onegin began, and under whose brooding person much of it remains), and contrary to the childhood passion of the precocious Marina Tsvetaeva, so taken with that "unlove scene on the bench," ${ }^{4}$ we cannot worry about Tatiana's fate. Muses do not have fates in that sense. Even to put that question to the text is a modal impropriety. Evgenii Onegin is neither a sentimental eighteenth-century novel nor a realistic novel of the Tolstoyan or Dostoevskian sort. ${ }^{35}$ Rather it belongs, as one critic aptly placed it, in a group of two together with Dead Souls: a one-time-only novelistic experiment in form and genre by a genius in a transitional period. ${ }^{36}$ For as the Formalist critics repeatedly remark, this is a novel in verse, and the verse component constantly deforms both the shape of the work and the personalities that mature within the work. ${ }^{37}$

Here we might heed one of America's most seasoned Pushkin scholars, Thomas Shaw, who warns: Do not overemphasize the prosiness of Pushkin's novel. Although the hero does not become a producer of poems, "actually, the entire novel suggests the importance of being poetic. Perhaps the basic underlying question of the novel is not simply the stages of development, but how a poet (or the poetic in man) can develop to maturity and remain, or once more become, poetic." 38 With these priorities in mind, the eponymous hero still remains the hero. Tatiana is best appreciated as a verse presence

34 See Tsvetaeva's ruminations on Tatiana's fate in My Pushkin: "A bench. On the bench, Tatiana. Then Onegin arrives, but he does not sit down; rather she gets up. Both stand. And only he speaks, all the time, for a long time, and she doesn't say a word. And here I understand that...this is love ... My first love scene was an unlove scene: he didn't love (that I understood), for that reason he did not sit down, she loved, for that reason she stood up, not for a minute were they together, they did nothing together, they did everything in reverse. He spoke, she was silent, he didn't love, she loved, he left, she remained... Tatiana sits on that bench forever." Marina Tsvetaeva, "Moi Pushkin," in her Izbrannaia proza v dvukh tomakh (New York: Russica, 1979), 2:249-302, esp. 260-61.

35 See Yury Lotman, "The Transformation of the Tradition Generated by Onegin in the Subsequent History of the Russian Novel" [1975], in Russian Views of Pushkin's "Eugene Onegin," 169-77.

36 Simon Franklin, "Novels without End: Notes on 'Eugene Onegin' and 'Dead Souls'," Modem Language Review 79 (1984): 372-83, esp. 372.

37 See especially Yury Tynyanov, "On the Composition of Eugene Onegin," in Russian Views of Pushkin's "Eugene Onegin,” 71-90.

38 Shaw sees three "phases" in the narrator's stance (youthful perceptivity, disenchantment, mature re-enchantment), and locates Onegin in an arrested second phase, ripe for reenchantment - although, of course, Onegin remains no poet. J. Thomas Shaw, "The Problem of Unity of Author-Narrator's Stance in Puškin's Evgenij Onegin,” 25-42, esp. 35. 
in the work, a highly condensed moral muse. She is there to enable what Shaw calls Evgeny's "mature re-enchantment," an inner process that, once having begun, releases him from the need to be narrated from without. In this reading, Evgenii Onegin is a finished work, over when it is over and complete as it stands. With its mixed sense of gratitude, nostalgia, and absolute irreversibility, the final leave-taking of the poet-narrator resembles Tatiana's abrupt departure several stanzas earlier, which had brought Evgeny to his senses. The truncated end is thus another well-constructed illusion, designed to launch the now matured and newly sobered hero across an unimagined threshold where we cannot follow him. In the final stanzas, Pushkin dismisses his readers with the same congenial, leisurely open-endedness that he invests in Onegin's unknown future. And it is Tatiana's very poeticity, I would suggest, that enabled this emergence of a genuinely novelistic hero. May we all part on such self-respecting terms with our creations.

\section{POSTSCRIPT TO “TATIANA": \\ THE REACTION FROM TAMBOVSK, PSKOV, NOVOSIBIRSK (1997)}

S. B. Prokudin, “Евгений Онегин” неисчерпаем...(Ответ американскому профессору Кэрол Эмерсон» ["Eugene Onegin" is inexhaustible... "A Reply to American professor Kerol Emerson]," Bulletin of Tambov University [Vestnik Tambovskogo universiteta] 3-4, 1996: 47-52.) Excerpts, beginning with the opening paragraphs:

The well-known American Slavist Kerol Emerson is irritated by Pushkin's Tatiana. She calls the attitude toward her a cult, and poses this question: "What, pray, makes this sentimental mix of naïveté, stubbornness and dimly outlined female qualities so persistent and irresistible?" And she proposes another variant, her own, for reading Tatiana's role in the novel. I will say outright that in my view, this "new" variant, which is emphasized assertively by the scholar but rigged one-sidedly, speaks to K. Emerson's concern to 'say something unfailingly new, unfailingly strange, something never before heard or seen by anyone' (Gogol). In her opinion, there are three creators of the novel: Pushkin, the narrator, and 
the narrator's friend Onegin. All three are in love with Tatiana, and the reason for this infatuation is the same-Eros, appearing because it is 'forbidden fruit.'

You will agree that from the point of view of a Russian reader, the proposed approach is a very peculiar one for grasping the secrets of Pushkin's novel, but it is customary for the idle trivialized consciousness of the West [osuetevsheyesia soznanie Zapada]. [...] [Pushkin's] novel opens up an 'abyss of space': a tragic struggle of good with evil, pangs of conscience, the drama of guilt." But for K. Emerson everything reduces to the illicit love between Tatiana and Onegin, which carries colossal erotic energy. She is not afraid to muddy crystal-clear depths. [...]

K. Emerson sympathetically cites the idea of the Canadian Slavist Douglas Clayton, who proposes that the aristocratism and elegance of the married Tatiana and her success in high society is in essence only a continuation of the fantasy that Tatiana's creator holds about himself. Clayton writes: 'Pushkin, the marginalized, the invalidated, the heretic (?! — S. P.) ... was metamorphosed into the heroine - not the hero- of his poem. Her acceptance at court, her brilliance, her tenderness, passion, and conviction - all these were qualities Pushkin sought for himself.' Here, for the first time dropped into the consciousness of the reader, is the idea of Tatiana's transparency; she is denied any independence from the author, she ceases to be a person acting according to the logic of her own character. And this, as we shall see, is the main goal of K. Emerson, who does not reckon with the fact we are dealing here with a realist novel, where the basic concern of its author is 'the truth of passions, the verisimilitude of feelings [...]'.

K. Emerson and other penetrating readers who think along her lines do not like Tatiana; they are irritated by her Russian soul, precisely by her soul. There's no doubt about it: an entire broad collection of impressionistic inspirations are utilized in order to convince the reader: Tatiana is not real, this is only an abstract fleshless image, a woman without a biographical fate, without a psychologically motivated character. [...]

Tatiana is drawn by Pushkin solely as a positive character. She does not succumb to the idol of idle vanity. 'Otdana' ['given away', cf. Tatiana's parting words to Onegin: «Но я другому отдана; / Я буду век ему верна» (But I am given to another / and shall be faithful to him forever)] does not mean subjection to human will, Tatiana is not a victim of this will, there is no despondent submissiveness in her. She is consciously fulfilling the 'will of heaven'. Tatiana's final monologue takes up 77 lines of verse. In 
21 of those lines she speaks as an 'I'. The heroine of the novel was raised in the [Russian] Orthodox spirit of wise humility [smirennomudrie], kindness, tolerance. In her we find the author's own idea of the 'selfrespect' of the Russian person, of fidelity to oneself, to one's national essence. $[\ldots]$

And finally: it is impossible to exhaust the text of Onegin, because everything created 'belongs to an order of eternally living and moving phenomena; each epoch pronounces its own judgment on them, but always leaves it to a subsequent epoch to say something new and more true' (Belinsky). Yes, but we add, with one condition: try not to distort a precious value, even if only someone else's.

\section{$\S$}

In response I wrote an intemperate letter - too intemperate, I now feel - which was published a year later together with Prokudin's counter-response (Vestnik Tambovskogo universiteta 4 [1997]: 70-77). Excerpts of my letter translated into English below:

«Открытое письмо С. Б. Прокудину» [An open letter to S. B. Prokudin] (19 May, 1997)

Much-esteemed Prof. Prokudin:

It was gratifying to learn that my article evoked such a lively and ardent response from your side. I won't hide the fact that your answer also did not leave me altogether indifferent. [ . . . In its tone and emotional charge, your answer resembles a huge counter-slogan. [24 points of rebuttal follow, of which 4 are reproduced here.]

3) What does the phrase 'idle trivialized consciousness of the West' mean in the context of a scholarly polemic? I wouldn't wish to identify my own understanding of Tatiana with an entire geopolitical region or cultural tradition.

4) It is difficult to argue against the fact that Eros is a reason for being in love. It's as much a truism as hunger being a reason for appetite. That's how people are created, and that is how Pushkin, in the half-jesting lines I cite, writes about it. In any event, 'forbidden fruit' is named by me as only one of the reasons that Onegin's passion might have been awakened. 
7) On Onegin as 'heretic' [in Douglas Clayton's phrase]. Here the translation is at fault, and the mistake is mine. The English word heretic is more polysemantic [than the Russian eretik]. It can refer not only to a blasphemer against true faith, but to a person who thinks in a dangerously untraditional manner, holding unorthodox ideas in the broadest sense, not only religious.

8) As regards the genre of EO: all that we know for absolute fact about the genre of 'EO' is that it is a novel in verse, and only a few critical schools consider it $100 \%$ realistic. Any critic has the right to reckon with that designation, or to ignore it. For Pushkin, the very concept of Realism did not exist. He proceeded from other criteria for organizing his creative work. What concerned Pushkin was verisimilitude and the boundaries of 'thingness' in poetry, its relationship to the ideal, and here he formulated his own special approach: 'true Romanticism' [istinnyi romantizm]. But to state that Pushkin pondered the question of Realism as such - that is to run ahead and err against the truth."

In his counter-response, Professor Prokudin reiterated that Tatyana without a palpable, flesh-and-blood "biographical fate" was unacceptable; that Dmitry Pisarev, 19th-century radical critic and debunker of Pushkin, had also criticized Tatiana as "sentimental and naïve" and now we have an attempt to "hammer that point home completely" [okonchatel'no utaldychit']; that it mystified him why "the speed with which a man in love hurries to a beloved woman should remind critics of descriptions of dreams or the logic of fairy-tales"; and that other "critical schools" might say what they please but he knew for a fact that "Russian Pushkin Studies considers Pushkin's novel realistic."

Meanwhile the essay was also receiving feedback of a more productive sort, such as the following by Yuri N. Chumakov (Novosibirsk State Pedagogical University), delivered in Pskov and published in Vokrug Pushkina, "Materials of the International Pushkin Conference (1-4 October, 1996, Pskov)" (The Pushkin Museum at Mikhailovskoe / Pskov State Pedagogical Institute): 
[Citations from "Tatiana" are back-translated from the often imprecise Russian version]

“«Евгений Онегин» в современном прочтении (по поводу статьи Caryl Emerson «Татьяна»" ["Eugene Onegin" in a contemporary reading (à propos of Caryl Emerson's article “Tatiana”)]

The growing popularity of Eugene Onegin in world culture indubitably flatters Russian national feeling. However, under these conditions it is easy to imagine interpretations that do not share our own prejudices ... the American Slavist K. Emerson has come out with a hypothesis according to which the final meeting of the heroes in Petersburg took place in Onegin's imagination. This radical re-interpretation - by no means impartial, but professional and dexterous - cannot leave any reader of Pushkin's novel in verse indifferent, since a new point of view on a classic episode fundamentally changes the whole picture of events and customary evaluations. Without attempting a detailed survey of K. Emerson's article, we intend here to lay out our provisional impression.

The emotional charge of K. Emerson's essay is contained in its negative attitude toward any presumption of superiority of Tatyana over Onegin. She is irritated by the 'inexhaustible list of virtues' in Pushkin's heroine; she does not agree with Dostoevsky, who 'elevated Tatiana's fate to the level of hagiography, highly valuing her everyday and spiritual qualities and ultimately raising her spousal fidelity to cosmic proportions' [... ]. Here K. Emerson is absolutely correct, since Dostoevsky, in his providential speech, interpreted the novel above and beyond the text, inserting into it categories of positive and negative hero convenient for the undemanding reader but mocked by Pushkin himself. Naturally she is "bothered by the degradation of Onegin, which is usually accompanied by an ecstatic attitude toward Tatiana,' polemically announcing that '.. this fascination, attractiveness and spiritual growth I dare to associate with the personality of Onegin, and not Tatiana.' This does not mean, however, an inversion of Dostoevsky's construct. Tatiana continues to fulfill the highest role in the text, since, in connection with the Author's love of her, 'she is equated not with a person, a woman, but with poetic inspiration itself.' Thus Tatiana does not cease to be the heroine of the novel, but at the same time her 'image in the work signifies much more than a simple linking of her character and the novel's plot. She is aesthetics itself.' Being a 'dynamic poetic principle' - that is, to some extent doubling the function of the Author - Tatiana does not want 'to spend herself impulsively merely to resolve the activity of the external plot.' Partly for that reason does she 
'so splendidly restrain and control herself' during the final meeting. But that's not all. K. Emerson sees the novel as something as 'complex and unpredictable as a kaleidoscope, abounding in thousands of potentials.' In this connection she proposes an 'absolutely untraditional means for reading the eighth chapter.'

The essence of the reading is that Tatyana, in that chapter, is a Muse - but not only the muse of the Author, which means the muse of everything we have read so far, but also the muse of Onegin, whom she inspires, and 'he only gradually becomes worthy of her.' Love begins to shape Onegin, but Tatiana does not allow him to explain himself to her, does not answer his letters, and 'under the influence of her image, as a symbol of the beginning of his new life and the appearance of a feeling of responsibility, memory is born.' In despair from loneliness, sunk in visions of the past, thirsting for Tatiana's presence, Onegin 'imagines his final visit with her. The words of her monologue are a conversation "between "two" men - between Onegin and his inner "I". As a result, and 'in contrast to the abstraction and "verselike quality" of Tatiana, Onegin is a dynamic novelistic figure, the hero of a "free novel," who must bear responsibility for his behavior in time.' Thus the plot finds closure, untraditionally and in a fully sublime manner. Simultaneously, the very thing that irritated K. Emerson is removed from the novel: the literal meaning of Tatiana's 'crowning lecture'.

Some grounds exist for suspecting a direct source for K. Emerson's idea. This is the suggestive parallel with V. Nabokov's Lolita, or more precisely, not so much with the novel itself as with one of its recent interpretations. A. A. Dolinin has managed to decode the double nature of the text of Lolita, where the main hero Humbert-Humbert speaks at length about his sinful attraction to the 'nymphet' and then composes, without demarcating the borders between 'confession' and 'novel,' the entire remaining history - with Lolita's letter, his meeting with her married and pregnant, and the murder of Clair Quilty. Of Nabokov's hero it is noted that 'his exit beyond the boundaries of his own "I", his leap from egoism to love,' in addition to the fact that 'passing over to another plane of existence, G. G. $[\mathrm{H}-\mathrm{H}]$ acquires something akin to creative force' 39 ...this entire process K. Emerson sees in Onegin of Chapter Eight, with his imaginary visit to Tatiana accompanied by references to Nabokov's commentary regarding the final meeting of Pushkin's heroes. One might even suggest that Nabokov's work over the translation and commentary to Eugene

39 A. A. Dolinin, “'Dvoinoe vremia' u Nabokova (ot Dara k Lolite)," in Puti i mirazhi russkoi kul'tury (St. Peterburg: Severo-Zapad, 1994), 310, 311. 
Onegin, parallel to Lolita, somehow influenced its conceptual structure, and as a result Lolita already shed light on little-noticed features of the poetics of Pushkin's novel.

There is nothing surprising about a retrospective illumination of the poetics and intertextuality of Eugene Onegin. Interpretations of the novel have always arisen supported by poetics that relate to more recent texts. Yu. N. Tynianov was able to write about the 'movement of verbal masses' after A. Bely's experiment in 'First Meeting,' 40 and even Dostoevsky interpreted Pushkin's heroes proceeding from the realistic and didactic presumptions of his own later epoch. K. Emerson's scenario can be linked with all this in complete seriousness; one must clarify, however, whether it is simply being inserted into the poetics of Onegin, or if it fundamentally modifies the novel's structural dependencies and conclusions on the plane of meaning. My thoughts on this will of necessity be brief.

Broadly applicable throughout the multi-planed structures of Eugene Onegin is the principle of penetrability/nonpenetrability. Even if we demarcate the boundaries of, say, Tatiana's Dream, this does not alter the diffusion of the dream throughout the entire novel. But most often boundaries are not noticeable, especially between outer and inner worlds. It was the same in Zhukovsky: a waking state passes over seamlessly into Svetlana's dream. In Onegin, the authorial 'I' remains unified even in incompatible spaces. The same is the case with the episodic townswoman (ch. 6), who is both a person in the novel and a reader of that same novel. Boundaries are often blurred between narrative and poetic plots, between their real and potential lines of development. K. Emerson's assumption about the inner event of the final encounter corresponds fully to the poetics of Onegin. Also correct are the comments concerning the wellknown 'dream quality' of Chapter Eight. In general, K. Emerson's tendency toward an immanent-poetic, rather than a socio-cultural, analysis of the text is very much in the spirit of our present day.

But diverse consequences inevitably follow if we transfer the final encounter of the heroes to the inner world of Onegin. The compositional balance that resulted when two real meetings frame two imagined ones (Tatiana's dream and her visit to the hero's estate), now inclines more toward the dream state. Consequently, even the heroes lose the unity of their worlds, insofar

40 See Chumakov, Yu. N. "Pervoe svidanie' A. Belogo v rusle oneginskoi traditsii," in Zhanrovo-stilevoe edinstvo khudozhestvennogo proizvedeniia (Novosibirsk: Myzhvuz. Sb. Nauch. Gr., 1989), 117-118. 
as Tatiana, functioning primarily as Muse, is pulled into the author's world, and thus her participation in the narrative plot fades. It seems to me that in the Eighth chapter Pushkin manages to balance all three hypostases of Tatiana: Princess N, Muse, and 'poor Tanya.' In our view, to emphasize unduly the various grounds for loving the heroine on the part of Pushkin, Narrator, and Onegin is to 'pilfer' the united authorial 'I,' woven together out of heterogeneous structures, and even slightly to blur the principle of immanence-since 'Pushkin' [as Author] is located beyond the space of the novel. I leave to one side all those objections which, it goes without saying, will arise from partisans of the traditional perception of Eugene Onegin. [...]"

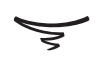

One final postscript is in order. In 1999, Olga Peters Hasty (Princeton University) published her Pushkin's Tatiana (University of Wisconsin Press), the first book-length study of this heroine in any language. In chapter 6, Hasty eloquently extends the debates around Tatiana's image to hint at a new appreciation of Pushkin's novel-in-verse:

That love be consummated is a novelistic expectation. Eugene Onegin is a defense of poetry - a genre, as Pushkin demonstrates, into which the novel can be absorbed. Pushkin leaves his hero and heroine not locked in embrace, but free to come into their own and to savor that moment of opening that Eugene ever feared and that Tatiana ever courted but believed to be lost. ... Surely this is the happiest of all endings. ${ }^{41}$

Olga Peters Hasty, Pushkin's Tatiana (Madison: University of Wisconsin Press, 1999), 211. Among the issues Hasty examines in exquisite detail are relationships between inner growth, love, and reading, and the psychological movement of the heroine's two pivotal experiences, the Letter and the Dream. "Tatiana," Hasty has remarked, "is the Russians' Mona Lisa." 